\title{
Trends in bacterial and fungal communities in ant nests observed with Terminal-Restriction Fragment Length Polymorphism (T-RFLP) and Next Generation Sequencing (NGS) techniques - validity and compatibility in ecological studies
}

\author{
Stafva Lindström ${ }^{\text {Corresp., }}$ 1, 2, 3 ， Owen Rowe ${ }^{4,5,6}$ ， Sari Timonen ${ }^{6}$ ， Liselotte Sundström ${ }^{1,2,3}$, Helena Johansson ${ }^{1,2}$ \\ ${ }^{1}$ Centre of Excellence in Biological Interactions, Department of Biosciences, University of Helsinki, Helsinki, Finland \\ 2 Tvärminne Zoological Station, University of Helsinki, Hanko, Finland \\ 3 Organismal and Evolutionary Biology, University of Helsinki, Helsinki, Finland \\ 4 Umeå Marine Sciences Centre, Umeå University, Hörnefors, Sweden \\ 5 Department of Ecology and Environmental Science, Umeå University, Umeå, Sweden \\ 6 Department of Microbiology, University of Helsinki, Helsinki, Finland \\ Corresponding Author: Stafva Lindström \\ Email address: stafva.lindstrom@helsinki.fi
}

Microbes are ubiquitous and often occur in functionally and taxonomically complex communities.

Unveiling these community dynamics is one of the main challenges of microbial research. Combining a robust, cost effective and widely used method such as Terminal Restriction Fragment Length

Polymorphism (T-RFLP) with a Next Generation Sequencing (NGS) method (Illumina MiSeq), offers a solid alternative for comprehensive assessment of microbial communities. Here, these two methods were combined in a study of complex bacterial and fungal communities in the nest mounds of the ant Formica exsecta, with the aim to assess the degree to which these methods can be used to complement each other. The results show that these methodologies capture similar spatiotemporal variations, as well as corresponding functional and taxonomical detail, of the microbial communities in a challenging medium consisting of soil, decomposing plant litter and an insect inhabitant. Both methods are suitable for the analysis of complex environmental microbial communities, but when combined, they complement each other well and can provide even more robust results. T-RFLP can be trusted to show similar general community patterns as Illumina MiSeq and remains a good option if resources for NGS methods are lacking. 
4 Trends in bacterial and fungal communities in ant nests observed with

5 Terminal-Restriction Fragment Length Polymorphism (T-RFLP) and Next

6 Generation Sequencing (NGS) techniques - validity and compatibility in

7 ecological studies

10 Stafva Lindström ${ }^{1,2,3}$, Owen Rowe ${ }^{4,5,6}$, Sari Timonen ${ }^{4}$, Liselotte Sundström ${ }^{1,2,3}$, Helena

11 Johansson ${ }^{1,2}$

$14{ }^{1}$ Centre of Excellence in Biological Interactions, Department of Biosciences, University of

15 Helsinki, P O Box 65, 00014 Helsinki, Finland

162 Tvärminne Zoological Station, J. A. Palménin tie 260, 10900 Hanko, Finland

$17{ }^{3}$ Organismal and Evolutionary Biology, University of Helsinki, P O Box 65, 00014 Helsinki

$18{ }^{4}$ Department of Microbiology, University of Helsinki, P O Box 56, 00014 Helsinki, Finland

195 Umeå Marine Sciences Centre, Umeå University, Norrbyn, 90571 Hörnefors, Sweden

$20{ }^{6}$ Department of Ecology and Environmental Science, Umeå University, 90187 Umeå, Sweden

23 Corresponding author: Stafva Lindström

24 Email address: stafva.lindstrom@helsinki.fi 


\section{Abstract}

Microbes are ubiquitous and often occur in functionally and taxonomically complex communities. Unveiling these community dynamics is one of the main challenges of microbial research. Combining a robust, cost effective and widely used method such as Terminal Restriction Fragment Length Polymorphism (T-RFLP) with a Next Generation Sequencing (NGS) method (Illumina MiSeq), offers a solid alternative for comprehensive assessment of microbial communities. Here, these two methods were combined in a study of complex bacterial and fungal communities in the nest mounds of the ant Formica exsecta, with the aim to assess the degree to which these methods can be used to complement each other. The results show that these methodologies capture similar spatiotemporal variations, as well as corresponding functional and taxonomical detail, of the microbial communities in a challenging medium consisting of soil, decomposing plant litter and an insect inhabitant. Both methods are suitable for the analysis of complex environmental microbial communities, but when combined, they complement each other well and can provide even more robust results. T-RFLP can be trusted to show similar general community patterns as Illumina MiSeq and remains a good option if resources for NGS methods are lacking.

\section{Introduction}

Microbes are the most numerous organisms on earth (Bertrand et al., 2011). Their small size and the difficulty of cultivating many (if not most) species has spurred the development of molecular techniques to study the taxonomy, community structure and functions of natural microbial communities. Several techniques such as Automated Ribosomal Intergenic Spacer Analysis (ARISA) (Ramette, 2009), Temperature Gradient Gel Electrophoresis (TGGE),

51 Denaturing Gradient Gel Electrophoresis (DGGE) (Nocker, Burr \& Camper, 2007) and Terminal 
53 al., 2013) have been developed for the assessment of complex microbial communities. The semi54 quantitative properties (Blackwood et al., 2003; Aiken, 2011), high reproducibility, low cost 55 (Thies, 2007) and the technical and analytical straightforwardness of T-RFLP has cemented it as one of the leading fingerprinting methods for several decades (Schütte et al., 2008). T-RFLP has successfully been used to evaluate the effects of spatial and temporal variation in the structure of microbial communities (Schütte et al., 2008; Robinson et al., 2009; Barnes et al., 2016). However, to obtain taxonomic identity of microbial community members, T-RFLP is usually combined with time-consuming and expensive preparation and sequencing of clone libraries (van Elsas \& Boersma, 2011).

Recent advances in high-throughput DNA sequencing techniques have made NGS (Next Generation Sequencing) methods such as Illumina MiSeq/HiSeq, IonTorrent and 454 pyrosequencing attractive alternatives for analysis of microbial communities (Teeling \& Glöckner, 2012). In contrast to T-RFLP, sequence data generated by these methods reveal taxonomic identity to the extent that designated sequence data is available (Weissbrodt et al., 2012; De La Fuente et al., 2014; Prakash et al., 2014). However, NGS datasets can be extensive, require more complex bioinformatic interpretation and the protocols and methods used for microbial NGS analysis are far from standardized (Amend, Seifert \& Bruns, 2010; Tedersoo et al., 2015; Balint et al., 2016). Complementing T-RFLP with NGS techniques can, however, offer a convenient way of generating and analyzing metagenomic microbial data, including the addition of taxonomic information achieved by NGS sequencing, to the T-RFLP fingerprints. This is especially useful for longitudinal studies, where substantial T-RFLP-fingerprinting data, including data generated prior to the NGS era, are available. Furthermore, different environments facilitate and promote microbiomes of different composition and diversity and the analysis should be carefully adapted to the specific study at hand (Buttigieg \& Ramette, 2014; Faust et al., 2015; Weiss et al., 2016). The few studies to date on bacteria, indicate that the patterns and trends in data generated by the two techniques are largely congruent (rumen bacteria (De La Fuente et al., 2014), bacteria in Antarctic soil (van Dorst et al., 2014), bacteria in tropical soil (Supramaniam et al., 2016)). Studies that utilize both T-RFLP and NGS data to explore fungal communities appear absent from the literature, as do studies comparing both bacterial and fungal communities using both techniques. 
Ants are frequent in most terrestrial environments (Vander Meer, 2012), often

84 being referred to as ecosystem engineers, due to their skills in manipulating the abiotic and biotic

85 properties of soil (Dauber, Schroeter \& Wolters, 2001; Jurgensen et al., 2008). While building their nests, the bioturbation and the selective picking of appropriate contruction materials create a soil chemistry that differs significantly from the one of the background soil (Kilpeläinen et al. 2007, Dostál et al. 2005). The distinct nest environment is clearly reflected by the nest microbiome: the nests of several mound building ant species contain a substantially higher microbial biomass (Dauber, Schroeter \& Wolters, 2001), more numerous and diverse fungal colonies (Duff et al., 2016) and significantly different microbial assemblages (Boots et al., 2012), than those of the reference soils.

The aim of this study was to evaluate the congruence of Illumina MiSeq and TRFLP data, based on the bacterial 16s and fungal ITS areas of the rRNA genes from complex environmental communities. To do this, the microbial communities inside the nests of the mound building ant Formica exsecta (Nylander 1846) were sampled over a two-year period. The bacterial and fungal communities in the $F$. exsecta mounds have not been studied previously, but here molecular microbial data of active nest mounds is reported, generated with both methodologies. The relative abundance patterns, diversities and sampling efficiencies generated by the two molecular techniques were compared, and the similarity of the functional, spatial, and temporal patterns were evaluated. The extent to which T-RFLP can be complemented with the taxonomic information gained from the NGS data was also assessed.

\section{Materials \& Methods}

\section{Ant species, study site and sampling}

Ants of the genus Formica are common in Northern Eurasia (Collingwood, 1979; Czechowski, Radchenko \& Czhechowska, 2002; Goropashnaya et al., 2007). Most species construct perennial above-ground mounds from litter and soil particles gathered from the surrounding forest floor (Jurgensen et al., 2008). The ant Formica exsecta used in this study is common (Douwes et al., 2012), and inhabits meadows, sunny woodland openings, and forest clearings (Sundstrom, Chapuisat \& Keller, 1996). The study sites are located on islands in the south-western archipelago of Finland, (Fig. S1) near Tvärminne zoological station 
112 (5984'196”N, 2320'182”E), where populations of $F$. exsecta have been monitored and studied

113 since 1994 (e.g. Sundström et al. 1996; Sundström et al. 2003; Vitikainen et al. 2011). The

114 islands represent typical biotopes of the SW coast of Finland, where granite outcrops, pine

115 spinneys, and dry meadows alternate with intermixed lusher patches of vegetation. The soil is

116 classified as lepotosol (http://www.fao.org/soils-portal/soil-survey/soil-classification/world-

117 reference-base/en/soil) of varying thickness due to the topographic factors. Scots pine and

118 Norway spruce dominate, together with ericaceous shrubs and species of Deschampsia and

119 Festuca. Sampling was approved by the land owner (Tvärminne Zoological station), and no

120 endangered or protected species were included in this study. Sampling was carried out once a

121 month in May, June, July, August and September in both 2013 and 2014. Four nest mounds were

122 sampled, two per island (F12 and F120 on Furuskär, J30 and J40 on Joskär, (Fig. S1) on each

123 consecutive sampling occasion, totalling 40 samples. The samples $(\sim 0.21)$ were collected by

124 hand from the inside of the mound at the depth of 10-15 cm using sterile gloves and placed in

125 clean plastic bags. Samples were stored at $-80^{\circ} \mathrm{C}$ until extraction of DNA.

\section{DNA extraction and PCR amplification for T-RFLP}

127

128

129

130

131

132

133

134

135

136

137

138

139

140 final 5 min elongation step at $72^{\circ} \mathrm{C}$. The PCRs were performed in duplicates and pooled into one 141 product. Sequences from the bacterial 16S rRNA region were amplified with the FAM-tagged

DNA was extracted from a $\sim 0.25 \mathrm{~g}$ subsample of nest mound material using the PowerSoil ${ }^{\circledR}$ DNA Isolation Kit (MoBio Laboratories Inc.) according to the manufacturer's instructions, with one exception being the use of TissueLyser II (Qiagen) for $3 \mathrm{~min}$ at $20000 \mathrm{rpm}$ during the cell lysis phase. DNA was eluted in $100 \mu \mathrm{l}$ of elution buffer, and the same DNA extractions were used for the T-RFLP analysis and Illumina MiSeq sequencing as described below. 2012), and the reverse primer ITS4 (TCCTCCGCTTATTGATATGC, White et al. 1990). PCR reactions were performed in a final volume of $15 \mu \mathrm{l}$, containing $0.75 \mu \mathrm{l}$ of each $10 \mu \mathrm{M}$ primer, $3.0 \mu \mathrm{l}$ GC $5 \mathrm{x}$ buffer, $0.3 \mu \mathrm{l}$ of $10 \mathrm{mM}$ dNTP's, $0.15 \mu l$ of Phusion $^{\text {TM }}$ DNA polymerase (Thermo Fischer), $0.75 \mu 1$ of DNA template and $8.7 \mu$ Milli-Q water. The PCR conditions were $30 \mathrm{~s}$ at 98 ${ }^{\circ} \mathrm{C}$; followed by 34 cycles of $10 \mathrm{sec}$ at $98{ }^{\circ} \mathrm{C}, 30 \mathrm{sec}$ at $54^{\circ} \mathrm{C}$, and $30 \mathrm{sec}$ at $72{ }^{\circ} \mathrm{C}$, followed by a 
142 forward primer 27F (AGAGTTTGATC(A/C)TGGCTCAG (Weisburg et al., 1991; Chung et al., 143 2004) and the reverse primer 1387R (GGGCGG(A/T)GTGTACAAGGC, Wade et al. 1998).

144 PCR reactions were performed as described above, with the exception of the step in cycling

145 before final elongation that was $40 \mathrm{sec}$ for bacteria.

146 Pooled duplicate PCR products from bacteria or fungi were purified with

147 Agencourt AMPure XP beads (1 DNA:1.2 AMPure, Beckman Coulter) and digested with the 148 restriction endonucleases HaeIII and MspI (Thermo Fischer) The reaction volumes were $10 \mu \mathrm{l}$ 149 purified PCR product, $1 \mu \mathrm{l}(10 \mathrm{U})$ of each enzyme, $2 \mu \mathrm{l} 10 \mathrm{xFastDigest}$ buffer and $17 \mu \mathrm{l}$ nuclease

150 free water. Samples were digested for $5 \mathrm{~min}$ at $37^{\circ} \mathrm{C}$. The labelled terminal restriction fragments 151 (T-RFs) were separated on an ABI-sequencer (model 3730, Applied Biosystems) with the 152 internal size standard GeneScan 500 ROX (Thermo Fischer) and analysed using GeneMapper 153 v.5 (Applied Biosystems).

\section{Analysis of T-RFLP data}

Peak data of T-RFs within the range of 70 to $400 \mathrm{bp}$ and above a threshold of units of fluorescence of 100 for bacteria, and 70 for fungi were extracted from GeneMapper and imported into T-rex (http://trex.biohpc.org) for filtering of noise (removal of peaks not considered to comprise unique T-RFs), alignment and binning (Culman et al., 2009). Exact matches were used, i.e. only single base errors $(+/-1 \mathrm{bp})$, and height of peaks (Dickie \& Fitzjohn, 2007; Aiken, 2011; Fredriksson, Hermansson \& Wilén, 2014) were used to determine the relative abundance. The peak data produced by the two enzymes (HaeIII and MspI) was filtered, aligned and binned in T-rex separately and pooled together (De La Fuente et al., 2014). The only instances where the data from the two enzymes were analysed separately was for matching the experimental T-RFs with the virtual T-RFs (described below) and for assessing the level of correlation between the ranked relative abundances of T-RFs and OTUs.

\section{Illumina MiSeq library preparation and sequencing}


171 Fischer) with a denaturation step of $98^{\circ} \mathrm{C}$ for $30 \mathrm{~s}$, followed by 15 cycles at $98{ }^{\circ} \mathrm{C}$ for $10 \mathrm{~s}, 65^{\circ} \mathrm{C}$

172 for $30 \mathrm{~s}, 72^{\circ} \mathrm{C}$ for $10 \mathrm{~s}$ followed by a final extension for 5 minutes at $72{ }^{\circ} \mathrm{C}$. PCR samples were

173 purified with Exonuclease I (Thermo Scientific) and Thermosensitive Alkaline Phosphatase

174 (FastAP; Thermo Scientific). A second PCR was performed on the template products with full-

175 length TruSeq P5 and index-containing P7 adapters. Cycling conditions were the same as the

176 first library preparation PCR, but with an increased number of cycles (18). DNA libraries were

177 quantified with Qubit (Invitrogen) and library quality assessed with a Bioanalyzer 2100

178 (Agilent), before pooling to equimolar amounts and submitted to sequencing. Due to technical

179 requirements, the same reverse primer as for the T-RFLP could not be used. The bacterial 16s

180 rRNA region was amplified using the primers 27F (AGAGTTTGATC(A/C)TGGCTCAG,

181 (Weisburg et al., 1991; Chung et al., 2004) and pD' (GTATTACCGCGGCTGCTG, (Edwards et

182 al. 1989). Libraries were otherwise constructed using the protocol described above. Sequencing

183 was carried out using an Illumina MiSeq v2 600 cycle kit in paired-end mode at the DNA

184 Sequencing and Genomics Laboratory, Institute of Biotechnology, University of Helsinki.

\section{Illumina MiSeq - bioinformatics data analysis}

186

Read filtering and OTU clustering (at 97\% identity) was performed using UPARSE

v. 8.1 (Edgar, 2013; Edgar \& Flyvbjerg, 2015), Table S1. Database SILVAv123 (Quast et al., 2013) was used as reference database for alignment of the bacterial sequences, and UNITE v7 (Kõljalg et al., 2013) for the fungal sequences. For taxonomic classification of the bacterial OTUs, the reference database RDP16s training set v.14 (Wang et al., 2007) was used, and for the

191 fungal OTUs the RDP ITS Warcup training set v.4 (Deshpande et al., 2016) was used. The

192 queries against the databases were done by using the RDP Naïve Bayesian Classifier with

193 bootstrap cut-off at 80\% (Wang et al., 2007). Singletons, doubletons, and sequences not

194 identified to the level of kingdom were removed prior to further analysis. The unprocessed

195 sequences are available at NCBI Sequence Read Archive, Bioproject number PRJNA399258.

\section{Species diversity, effective sampling estimates, and functional}

197 organisation performed in the statistical framework R using the function specaccum in package vegan v. 2.4-5 
200 (Oksanen et al., 2011), and Good's estimate (Good, 1953) of sampling coverage. The curves

201 visualize the level of sampling effort as a function of the accumulated number of samples with a

202 more saturated curve indicating a better sampling effort. Good's estimate indicates the

203 proportion of the population that has been captured by the sampling or sequencing (Good, 1953).

204 Furthermore, the number of T-RFs and OTUs were counted, and the mean value of the total

205 fungal and bacterial diversity was estimated by calculating respective Shannon-Wiener's

206 diversity index $\left(H^{\prime}\right)$ on the T-RFs and OTUs using the diversity function in R, package vegan

207 (Oksanen et al., 2011).

The functional organization $(F o)$ of bacteria and fungi obtained with the two molecular methods, was compared by estimating Pareto-Lorenz curves (performed in JMP v.11,

210 SAS Institute Inc.). To assess the degree of functional organization, the cumulative normalized

211 number of T-RFs or OTUs were plotted against their respective cumulative normalized height

212 (T-RFs) or sequence abundance (OTUs) (Marzorati et al., 2008). This always creates a convex

213 curve as the values are positive by default. The deviation of the curve from the $45^{\circ}$ diagonal line

214 (representing perfect evenness with no functional organization) indicates the degree of functional

215 organization (Mertens, Boon \& Verstraete, 2005; Wittebolle et al., 2009). The Fo value is

216 determined from the y-axis where the curve intercepts with the $20 \% \mathrm{x}$-axis line. A Fo value of

$21725 \%$ represents a community of high evenness with no distinct structure in terms of species

218 dominance. A community at the $F o$ value of $45 \%$ is more functionally organized due to lower

219 evenness, and a value of $80 \%$ for the $F o$ stands for a highly specialized community, dominated

220 by a low number of species on which the functional stability depends. The level of $F o$ could also

221 be defined as the community's ability to rebuild itself to the level of functionality it had before a

222 disturbance (Marzorati et al., 2008).

223

224

225

226

227

228

229

To further assess similarity between the datasets produced by T-RFLP and Illumina sequencing, the TRFs were rarefied without replacement to the lowest peak height, and OTUs to the lowest number of reads (Table S1), before Bray-Curtis inter-sample dissimilarity matrices were generated. These matrices were then subjected to principal co-ordinates analysis (PCoA), and a PERMANOVA (a one-way nonparametric permutational multivariate analysis of variance, Anderson, 2001), with 999 permutations was used to test the effects of year, month, nest and island on the matrices. To ensure that the results for the bacterial OTUs were robust (Morton et 
230 al. 2017, see below), PCoAs were also performed on Bray-Curtis matrices contructed from log

231 transformed data, and on Morisita and Jaccard distance matrices. The uniformity of the T-RFLP

232 and the OTU matrices was tested with Mantel's tests (method 'pearson', significance based on

233999 permutations). Rarefying and the analyses described above were carried out in $\mathrm{R}$ with

234 package vegan (Oksanen et al., 2011). Finally, the relative abundance patterns of the (non-

235 rarefied) T-RFs and the OTUs were compared, with the expectation that both techniques would

236 show similar proportions of abundances. The T-RFs (enzymes analysed separately), and the

237 equivalent number of OTUs were ranked from the highest to the lowest (T-RFs according to

238 their height, and the OTUs according to their read abundance), and the correlations (Pearson's

239 rho) tested by t-test, were performed in JMP v.11 (SAS Institute Inc.).

240 Virtual T-RFs

241

242

243

244

245

246

247

248

249

250

251

252

253

254

255

256

257

258

To match the Illumina OTUs and their identities with the experimental T-RFs, a virtual restriction was performed on the 200 most abundant OTUs of each bacteria and fungi. These subsets were chosen based on the outcome of the correlation test, and the number of sequences they covered. The OTU sequences were first aligned (ClustalX2, Larkin et al. 2007) to confirm the coverage of the entire targeted 16s region (bacteria) or the ITS2 region (fungi) and the starting points of the primers were identified. Virtual T-RFs were generated with the Webcutter on-line tool (http://rna.lundberg.gu.se/cutter2/), for the two enzymes separately. The experimental T-RFs that were generated were matched with virtual T-RFs in Excel, and taxonomic identities were derived from the classification of the Illumina MiSeq sequences. A taxa was considered as being represented by the experimental T-RFs only if restriction sites for both enzymes were detected on the Illumina OTU sequences.

\section{Results}

The T-RFLP-analysis generated 129 (HaeIII) and 120 (MspI) unique bacterial TRFs ( $\mathrm{n}=37)$, and 102 (HaeIII) and 124 (MspI) fungal T-RFs $(\mathrm{n}=36)$, respectively (Table 1). The Illumina MiSeq sequencing yielded in total (i.e. for all samples) 1896920 bacterial reads (16S sequences), and 3274825 fungal reads (ITS2 sequences), of high quality ( $\mathrm{n}=38$ for both bacteria and fungi) (Table S1 and SI_Bioinformatics). These clustered into 4699 unique bacterial and 2315 unique fungal OTUs (Table 1). The Good's estimate of coverage for the T-RF data 
259

260

261

262

263

264

265

266

267

268

269

270

271

272

273

274

275

276

277

278

279

280

281

282

283

284

285

286

287

288

suggested that $97.9 \%$ of the bacterial, and $93 \%$ of the fungal diversity had been captured by the method, whereas the coverage for the OTUs was $99.9 \%$ and $99.4 \%$, respectively (Table 1). The species accumulation curves (Fig. 1) showed a similar pattern, with the curves for the T-RFs being generally less flattened towards the end of their curves, particularly so in the fungal data. Only the bacterial OTU communities reached asymptote, suggesting high sampling efficiency (Fig. 1). The mean Shannon-Wiener diversity index for the T-RFs was lower than the OTUs for both the bacterial (3.35 vs. 5.69 ) and fungal (2.71 vs. 3.48) (Table 1). The Pareto-Lorenz curves suggested a high $F o$, indicating a high functional organization, for both the bacterial, and fungal communities, regardless of the method used (Fig. 2). In the bacterial data, $20 \%$ of the T-RFs and OTUs accounted for $85 \%$ and $87 \%$ of the species abundance, respectively (Fig. 2A). The corresponding values for the fungal T-RFs and OTUs projected $73 \%$ and $95 \%$, respectively (Fig. 2B).

The PCoAs indicated clustering of bacterial communities within islands and nests, in both the T-RF and OTU data, but the clustering was more pronounced in the OTU data (Fig. $3 \mathrm{~A}$ and $3 \mathrm{~B}$ ). The horseshoe pattern in the bacterial NGS data remained in the PCoA analysis when it was repeated with log-transformed data, and also when the analysis was performed on alternative distance matrices (Fig. S2A-E), suggesting a true pattern rather than an artefact. A clustering by month (Fig. S3) was indicated for the T-RFs, which seemed mainly driven by the values of September. No such indication was seen for the OTUs. The PERMANOVA confirmed the effect of month for the bacterial T-RFs. The PERMANOVA suggested compliance between the two methods, showing significant effects of island and nest for both the T-RF and OTU data (Table 2). The effect of year was not significant, neither for the T-RFs nor the OTUs (Table 2). The PCoAs from the fungal T-RF and OTU data indicated clustering across both island and nest (Fig. 3C and 3D), with the fungal OTU data showing a much more pronounced clustering than the T-RF data (Fig. 3C and 3D). The PERMANOVA showed significant effects of island and nest for both T-RFs and OTUs in the fungal data, suggesting full compliance between the two methods for all the tested effects (Table 2). The Mantel tests showed moderate to good correspondence between the T-RF and the OTU data, being significantly correlated (Pearson's $r h o=0.743, P \leq 0.001$, and $0.574, P \leq 0.001)$ for the bacterial and the fungal data sets, respectively. 
290 highest to lowest (encompassing 52\% (HaeIII) and 50\% (MspI) of the bacterial, and 78\% and

$29181 \%$ of the fungal OTU sequences), were highly and significantly correlated (Pearson's rho =

2920.949 (HaeIII), and 0.849 (MspI), respectively for the bacterial data, and 0.953 and 0.904 ,

293 respectively for the fungal data; $P \leq 0.001$ in all cases; Fig. 4A $-4 \mathrm{D}$. Of all the bacterial OTUs,

$29489 \%$ were assigned identities at the phylum, and 53\% at the family level (Table 3), whereas the

295 corresponding values for the fungal OTUs were $85 \%$, and $39 \%$, respectively (Table 3, Fig. S4A $296-$ S4B).

297

298

299

300

301

302

303

304

305

306

307

308

309

310

311

312

313

314

315

316

317

318
The 200 most abundant bacterial OTUs, on which the virtual restriction was performed, comprised approximately $60 \%$ of all bacterial OTU sequences. Taxonomic information (based on the taxonomic identification of the Illumina OTUs) was available for $66 \%$ of the 200 bacterial OTUs down to the level of family. The enzyme HaeIII successfully cut nearly all (99\%) of the most abundant 200 OTUs, whereas MspI cut 86\%. Matching virtual T-RF with the T-RFs generated from soil samples returned 93 taxonomic items, with restriction patterns from both enzymes (Table S2). Seventeen different restriction patterns were found, three of which were shared between several phyla, whereas 14 patterns were unique at the order level, and six of these at the family level (Table S2). No taxonomic information was available for three of the restriction patterns below the class level, and one pattern returned phylum only. Four of the six identified families (Burkholderiaceae, Caulobacteraceae, Nocardioidaceae and Streptomycetaceae) belonged to the bacterial families ranked as the most abundant according to the Illumina MiSeq data (Table 3).

The corresponding fungal data, based on the 200 most abundant fungal OTUs, on which the virtual restriction was performed, comprised approximately $87 \%$ of all fungal OTU sequences Taxonomic information down to the family level was available for $50 \%$ of the fungal OTUs. A virtual HaeIII restriction site was found in 97\%, and an MspI restriction site in 93\% of the fungal OTUs. Matching the virtual T-RFs with the T-RFs generated from nest mound soil samples returned 41 taxonomic items, with restriction patterns from both enzymes. These taxonomic items represent 14 distinct restriction patterns, all of which were unique at the level of phylum (Table S3). Nine unique patterns were identified at the order level, and 8 patterns were further identified to the family level. Four patterns were identified to phylum only. Of the 
319 identified families, the Tremellales_incertae_sedis and Venturiaceae were among the most

320 abundant ones according to the Illumina MiSeq data (Table 3).

\section{Discussion}

In this study, T-RFLP fingerprinting and Illumina sequencing were used to analyze

323 the bacterial and fungal communities in the nest mounds of the ant F. exsecta. The results show

324 that the combination of the two approaches is well suited to study microbial communities of high complexity, and that they provide similar, yet complementary information. With both methods, the microbial communities showed high and similar functional organization, and similar spatiotemporal patterns across both nest mounds and sampling occasions. Comparisons between fungi and bacteria also revealed that bacterial communities were more comprehensively sampled than fungal communities.

The number of T-RFs obtained in this study were similar in magnitude to other comparable studies of soil microbial communities in polar, pasture, meadow, agricultural and forest soils, both for bacteria (Blackwood et al., 2003; Frey et al., 2009; Anderson et al., 2011; van Dorst et al., 2014), and fungi (Schwarzenbach, Enkerli \& Widmer, 2007; Boots et al., 2012; van Dorst et al., 2014). Similarly, the number of microbial sequences, the sum of refined OTUs, and the resultant unique OTUs identified in this study, were in good correspondence with recent NGS studies of soil bacteria (Lazzaro, Hilfiker \& Zeyer, 2015; Supramaniam et al., 2016) and fungi (Meiser, Bálint \& Schmitt, 2014). In general, the number of defined, unique OTUs was much higher than the number of respective T-RFs (approximately 36 times the bacterial, and 19 times the fungal T-RFs). Nevertheless, when ranked per relative abundance, the high Pearson correlation suggest similar proportions of the most abundant T-RFs and OTUs, for both bacteria and fungi. This does not automatically mean that the most abundant T-RFs correspond with the most abundant OTUs or vice versa, but it indicates that the most abundant taxa were obtained by both techniques, in similar relative proportion.

Comparisons between the sampling coverage, i.e. Good's estimates, and the species accumulation curves of fungi and bacteria, revealed that bacterial communities were more comprehensively sampled than fungal communities. Notably, the asymptote was not reached for

347 neither fungi nor bacteria using T-RFLP, suggesting undersampling by this technique (Zhou et

348 al., 2008). Only a small fraction of microbial diversity is sampled with this (and similar) methods 
349 (Jankowski, Schindler \& Horner-Devine, 2014), resulting in low detection sensitivity and flatter 350 species accumulation curves. Comparatively, the asymptote was reached for bacteria, and the 351 curve better saturated for fungi using NGS, highlighting the power of this method to detect rarer 352 taxa. Consequently, the diversity estimates were also lower for fungi than for bacteria. Technical 353 factors likely to contribute to the observed differences in sampling success include the length of 354 sequenced fragments, the choice of genes sequenced, and primer specificity. The technical 355 requirement of using different primer pairs for both methods, resulted in fragments of differing 356 length. The bacterial Illumina sequences were $\sim 500 \mathrm{bp}$ (Timonen et al., 2017), and the T-RFLP sequences $\sim 1200$ bp (Muehling et al., 2016) long, respectively, whereas the fungal target sequence was 280-310 bp long (Ihrmark et al., 2012) for both methods. Thus the longer fragment can be expected to provide more phylogenetic information, leading to a finer tuned OTU clustering. For the T-RFLP differentiation, the longer fragment could provide an increased number of enzyme cutting sites, which could partly explain the higher yield of the bacterial TRFs compared to the fungal T-RFs. In addition, the bacterial $16 \mathrm{~S}$ gene is highly conserved, and successfully targets most bacterial phyla (Větrovský et al., 2013). Developing fungal primers with similar attributes has proven more challenging (Martin \& Rygiewicz, 2005; Asemaninejad et al., 2016), as fungal markers fulfilling the criteria of being of suitable length and specificity, yet not discriminating against any fungal taxa are not available (Lindahl et al., 2013). This is further compounded by the fact that a substantial proportion of the fungal ITS sequences in the International Nucleotide Sequence Database are incomplete, with fragmentary regions in the ITS1 and ITS2 subsections (Nilsson et al., 2009). From a biological standpoint, it is nevertheless possible that the fungal communities are less diverse, owing to abiotic factors (De Vries \& Shade, 2013; Wagg et al., 2014). functional organization in the nest mounds of $F$. exsecta. The Pareto-Lorenz curves suggested a high functional organization of the microbial communities inside the nest mounds. This suggests that the number of dominant species within the community is relatively low (Wittebolle et al., 2009), given that a high functional organization signals numerical dominance by a few species

377 (Mertens, Boon \& Verstraete, 2005; Marzorati et al., 2008; Wittebolle et al., 2008; Gonzalez-Gil $378 \&$ Holliger, 2011). This agrees with our finding that $50 \%$ of the fungal sequences, and $60 \%$ of 379 the bacterial sequences were found among the 200 most abundant OTUs. Such communities are 
380 often specialized, but potentially susceptible to disturbance, requiring a long recovery time for 381 regaining their functionality. Conversely, a community of high species evenness is expected to

382 cope better with environmental disturbances (Marzorati et al., 2008). The high level of functional

383 organization suggests that the microbial communities in the nest mounds may be specialized and

384 strongly affected by the habitat they are associated with (Edwards et al., 2011; Boots \& Clipson,

385 2013; Cai et al., 2014). Further study to confirm an existent influence of the $F$. exsecta nest

386 environment on the bacterial and fungal communities, compared with the effect of a reference

387 substrate, would be required.

Both techniques also captured similar community patterns in bacteria and fungi.

The results suggest that microbial communities were primarily structured at the level of nest mounds, with a more distinct clustering in the OTU data. Structure at the level of island was also found, but this effect may be compromised by the low sample size, and a more extensive study with a larger number of sampling sites would be required to confirm this effect. In this study, the higher sequencing depth (i.e. higher number of OTUs generated) likely contributed to the

394 slightly lower correspondence between NGS and T-RFLP matrices, compared to that found in e.g. (Pilloni et al., 2012) and (De La Fuente et al., 2014). A higher sequencing depth is likely to reveal rarer taxa, which would not have been defined in earlier studies, and are inaccessible to methods such as T-RFLP.

Although even greater taxonomic details for the T-RFs, and a better agreement between the two methods could be achieved by the use of additional enzymes (Dunbar, Ticknor \& Kuske, 2001; Edwards \& Turco, 2005), the overall taxonomic information obtained was comparable to those reported for extensive T-RFLP studies involving clone libraries (Axelrood et al. 2002; Youssef \& Elshahed 2009, Lin et al. 2011). The correlation between the relative abundance of T-RFs, and the equivalent number of the most abundant OTUs was significant both for bacteria and fungi, which corroborates the congruence between the methods. The outcome of the correlation served as a workable guideline for the number of OTUs (200) that were forwarded to the in silico T-RF cuttings. For both bacteria and fungi, the virtual T-RFLP generated restriction patterns from the majority of this subset of OTU sequences obtained by the 408 Illumina sequencing. The bacterial OTUs were assigned to 13 different phyla, with roughly half $409(52 \%)$ being assigned to the phyla of Proteobacteria and Actinobacteria, both of which were also 
410 captured by the matching of T-RFs. At lower taxonomic levels, T-RFs and the virtual restriction 411 cutting patterns corresponded to the taxonomic families of Burkholderiaceae, Caulobacteraceae, 412 Nocardioidaceae and Streptomycetaceae. In the fungal data, the Illumina sequencing captured 413 four phyla, whereas, based on the virtual restriction, the T-RFLP only captured two phyla, the 414 Ascomycota and Basidiomycota. At lower taxonomic levels, the virtual restriction captured the 415 families Tremellales incertae sedis, and Venturiaceae, both of which were the most abundant 416 fungal families captured by the Illumina sequencing.

The bacterial and fungal taxa captured by our analysis are abundant in soil

418 environments (Acosta-Martínez et al., 2008; Buée et al., 2009; Anderson et al., 2011; Voglmayr

419 et al., 2011; Lanzén et al., 2015; DeAngelis et al., 2015). Furthermore, the bacterial genera

420 belonging to Burkholderiaceae have also been shown to be associated with ant genera such as,

421 Camponotus (He et al., 2011), Cephalotes (Russell et al., 2009; Kautz et al., 2013), and

422 Tetraponera (Van Borm et al., 2002). Several genera representing both Proteobacteria and

423 Actinobacteria, and sequences matching Burkholderia were also present in the transcriptomic

424 data of $F$. exsecta (Johansson et al., 2013). The two fungal families that were captured by both T-

425 RFLP and Illumina (Tremellales incertae sedis and Venturiaceae) are not currently defined in the 426 literature as having any association with ants. However, the literature on fungi associated with 427 ants is focused solely on the fungus-farming ants and the restricted number of fungal species 428 they cultivate, or the few insect pathogenic fungi studied in connection with ants (Hughes et al., 429 2004).

\section{Conclusions}

Thorough assessment of complex microbial communities is challenging, and the use of multiple methods is often required in order to achieve a comprehensive outcome. This study describes certain steps at which technical choices during the process have substantial impact on the outcome, pinpointing some plausible reasons for non-conformity between the two methods. Overall, this study shows that both T-RFLP and Illumina sequencing are suitable for analysis of the fungal and bacterial communities in nest mounds of ants, but when the two

437 techniques are combined, it can provide an even more robust dataset. Furthermore, this study 438 validates the use of both techniques when addressing the topic of microbial communities in 
439 complex environments such as ant nest mounds, both independently or to support findings within 440 comparable studies. In particular, when comprehensive longitudinal studies based on T-RFLP 441 exist, supplementing the fingerprinting data with NGS is a practical solution. Although refining 442 the results gained by the two methods into a reliable synthesis requires testing of overall 443 compliance, T-RFLP can be trusted to reveal the same general community patterns as NGS 444 (Illumina MiSeq), and is a good option if resources for NGS are limited.

\section{Acknowledgements}

447 We thank our technician Heini Ali-Kovero for her valuable input during the laboratory assays, 448 Minna-Maarit Kytöviita for her kind assistance in identifying the soil type and typical plants of 449 the sampling site, Claire Morandin for her valuable help with the bioinformatics and Hanna $450 \quad$ Sinkko for all her statistical support.

\section{References}

452

453

454

455

456

457

458

459

460

461

462

463

464

465

Acosta-Martínez V., Dowd S., Sun Y., Allen V. 2008. Tag-encoded pyrosequencing analysis of bacterial diversity in a single soil type as affected by management and land use. Soil Biology and Biochemistry 40:2762-2770. DOI: 10.1016/j.soilbio.2008.07.022.

Aiken JT. 2011. Terminal Restriction Fragment Length Polymorphism for Soil Microbial Community Fingerprinting. Soil Science Society of America Journal 75:102. DOI: 10.2136/sssaj2008.0088.

Amend AS., Seifert KA., Bruns TD. 2010. Quantifying microbial communities with 454 pyrosequencing: Does read abundance count? Molecular Ecology 19:5555-5565. DOI: 10.1111/j.1365-294X.2010.04898.x.

Anderson MJ. 2001. Permutation tests for univariate or multivariate analysis of variance and regression. Canadian Journal of Fisheries and Aquatic Sciences 58:626-639. DOI: 10.1139/f01-004.

Anderson CR., Condron LM., Clough TJ., Fiers M., Stewart A., Hill RA., Sherlock RR. 2011. Biochar induced soil microbial community change: Implications for biogeochemical cycling 
466

467

468

469

470

471

472

473

474

475

476

477

478

479

480

481

482

483

484

485

486

487

488

489

490

491

492

493

of carbon, nitrogen and phosphorus. Pedobiologia 54:309-320. DOI:

10.1016/j.pedobi.2011.07.005.

Asemaninejad A., Weerasuriya N., Gloor GB., Lindo Z., Thorn RG., Kauserud H. 2016. New Primers for Discovering Fungal Diversity Using Nuclear Large Ribosomal DNA. PLOS ONE 11:e0159043. DOI: 10.1371/journal.pone.0159043.

Axelrood PE., Chow ML., Radomski CC., McDermott JM., Davies J. 2002. Molecular characterization of bacterial diversity from British Columbia forest soils subjected to disturbance. Canadian journal of microbiology 48:655-674. DOI: 10.1139/w02-059.

Balint M., Bahram M., Murat Eren A., Faust K., Fuhrman JA., Orn Lindahl B., O 'hara RB., Opik M., Sogin ML., Unterseher M., Tedersoo L. 2016. Millions of reads, thousands of taxa: microbial community structure and associations analyzed via marker genes FEMS Microbiology Reviews Advance Access. FEMS Microbiology Reviews 40:686-700. DOI: 10.1093/femsre/fuw017.

Barnes CJ., van der Gast CJ., Burns CA., McNamara NP., Bending GD. 2016. Temporally Variable Geographical Distance Effects Contribute to the Assembly of Root-Associated Fungal Communities. Frontiers in microbiology 7:195. DOI: 10.3389/fmicb.2016.00195.

Bertrand J-C., Caumette P., Lebaron P., Matheron R., Normand P., Sime-Ngando T. 2011. Environmental Microbiology:Fundamentals and Applications. Dordrecht: Springer Science Business Media B.V. DOI: 10.1007/978-94-017-9118-2.

Blackwood CB., Marsh T., Kim S., Paul E a. 2003. Terminal Restriction Fragment Length Polymorphism Data Analysis for Quantitative Comparison of Microbial Communities Terminal Restriction Fragment Length Polymorphism Data Analysis for Quantitative Comparison of Microbial Communities. Applied and Environmental Microbiology 69:926932. DOI: 10.1128/AEM.69.2.926.

Boots B., Clipson N. 2013. Linking ecosystem modification by the yellow meadow ant (Lasius flavus) to microbial assemblages in different soil environments. European Journal of Soil Biology 55:100-106. DOI: 10.1016/j.ejsobi.2013.01.002.

Boots B., Keith AM., Niechoj R., Breen J., Schmidt O., Clipson N. 2012. Unique soil microbial 
494

495

496

497

498

499

500

501

502

503

504

505

506

507

508

509

510

511

512

513

514

515

516

517

518

519

520

521

assemblages associated with grassland ant species with different nesting and foraging strategies. Pedobiologia 55:33-40. DOI: 10.1016/j.pedobi.2011.10.004.

Van Borm S., Buschinger A., Boomsma JJ., Billen J. 2002. Tetraponera ants have gut symbionts related to nitrogen-fixing root-nodule bacteria. Proceedings of the Royal Society BBiological Sciences:2023-2027. DOI: 10.1098/rspb.2002.2101.

Buée M., Reich M., Murat C., Morin E., Nilsson RH., Uroz S., Martin F. 2009. 454 Pyrosequencing analyses of forest soils reveal an unexpectedly high fungal diversity. New Phytologist 184:449-456. DOI: 10.1111/j.1469-8137.2009.03003.x.

Buttigieg PL., Ramette A. 2014. A guide to statistical analysis in microbial ecology: a community-focused, living review of multivariate data analyses. FEMS Microbiology Ecology 90:543-550. DOI: 10.1111/1574-6941.12437.

Cai H., Jiang H., Krumholz LR., Yang Z. 2014. Bacterial community composition of sizefractioned aggregates within the phycosphere of cyanobacterial blooms in a eutrophic freshwater lake. PLoS ONE 9. DOI: 10.1371/journal.pone.0102879.

Cao Y., Van De Werfhorst LC., Dubinsky EA., Badgley BD., Sadowsky MJ., Andersen GL., Griffith JF., Holden PA. 2013. Evaluation of molecular community analysis methods for discerning fecal sources and human waste. Water Research 47:6862-6872. DOI: 10.1016/j.watres.2013.02.061.

Chung J., Ha E-SS., Park H-RR., Kim S. 2004. Isolation and characterization of Lactobacillus species inhibiting the formation of Streptococcus mutans biofilm. Oral Microbiology and Immunology 19:214-216. DOI: 10.1111/j.0902-0055.2004.00137.x.

Collingwood C. 1979. The Formicidae (Hymenoptera) of Fennoscandia and Denmark. Fauna Entomol. Scand. 8:1-174.

Culman SW., Bukowski R., Gauch HG., Cadillo-Quiroz H., Buckley DH. 2009. T-REX: software for the processing and analysis of T-RFLP data. Bmc Bioinformatics 10:171. DOI: 10.1186/1471-2105-10-171.

Czechowski W., Radchenko A., Czhechowska W. 2002. The Ants (Hymenoptera, Formicidae) of Poland. Museum of Institute of Zoology. 
522 Dauber J., Schroeter D., Wolters V. 2001. Species Specific Effects of Ants on Microbial Activity

523

524

525

526

527

528

529

530

531

532

533

534

535

536

537

538

539

540

541

542

543

544

545

546

547

548

549 and N- Availability in the Soil of an Old-Field. European Journal of Soil Biology 37:259261. DOI: 10.1016/S1164-5563(01)01094-9.

DeAngelis KM., Pold G., Topcuoglu BD., van Diepen LTA., Varney RM., Blanchard JL., Melillo J., Frey SD. 2015. Long-term forest soil warming alters microbial communities in temperate forest soils. Frontiers in Microbiology 6:104. DOI: 10.3389/fmicb.2015.00104.

Deshpande V., Wang Q., Greenfield P., Charleston M., Porras-Alfaro A., Kuske CR., Cole JR., Midgley DJ., Tran-Dinh N. 2016. Fungal identification using a Bayesian classifier and the Warcup training set of internal transcribed spacer sequences. Mycologia 108:1-5. DOI: 10.3852/14-293.

Dickie I a., Fitzjohn RG. 2007. Using terminal restriction fragment length polymorphism (TRFLP) to identify mycorrhizal fungi: A methods review. Mycorrhiza 17:259-270. DOI: 10.1007/s00572-007-0129-2.

van Dorst J., Bissett A., Palmer AS., Brown M., Snape I., Stark JS., Raymond B., McKinlay J., Ji M., Winsley T., Ferrari BC. 2014. Community fingerprinting in a sequencing world. FEMS microbiology ecology 89:316-30. DOI: 10.1111/1574-6941.12308.

Dostál P., Březnová M., Kozlíčková V., Herben T., Kovář P. 2005. Ant-induced soil modification and its effect on plant below-ground biomass. Pedobiologia 49:127-137. DOI: 10.1016/j.pedobi.2004.09.004.

Douwes P., Abenius J., Cederberg B., Wahlstedt U. 2012. Nationalnyckeln till Sveriges flora och fauna. Steklar: Myror-getingar. Hymenoptera: Formicidae-Vespidae. Uppsala: ArtDatabanken, SLU.

Duff LB., Urichuk TM., Hodgins LN., Young JR., Untereiner WA. 2016. Diversity of fungi from the mound nests of Formica ulkei and adjacent non-nest soils. Canadian Journal of Microbiology 62:562-571. DOI: 10.1139/cjm-2015-0628.

Dunbar J., Ticknor LO., Kuske CR. 2001. Phylogenetic Specificity and Reproducibility and New Method for Analysis of Terminal Restriction Fragment Profiles of 16S rRNA Genes from Bacterial Communities Phylogenetic Specificity and Reproducibility and New Method for 
550

551

552

553

554

555

556

557

558

559

560

561

562

563

564

565

566

567

568

569

570

571

572

573

574

575

576

577

Analysis of Terminal Restrictio. Applied and Environmental Microbiology 67:190-197. DOI: 10.1128/AEM.67.1.190.

Edgar RC. 2013. UPARSE: highly accurate OTU sequences from microbial amplicon reads. Nature methods 10:996-8. DOI: 10.1038/nmeth.2604.

Edgar RC., Flyvbjerg H. 2015. Error filtering, pair assembly and error correction for nextgeneration sequencing reads. Bioinformatics 31:3476-3482. DOI:

10.1093/bioinformatics/btv401.

Edwards A., Anesio AM., Rassner SM., Sattler B., Hubbard B., Perkins WT., Young M., Griffith GW. 2011. Possible interactions between bacterial diversity, microbial activity and supraglacial hydrology of cryoconite holes in Svalbard. The ISME Journal 5:150-160. DOI: 10.1038/ismej.2010.100.

Edwards U., Rogall T., Blöcker H., Emde M., Böttger EC., Bottger EC., Blocker H., Emde M. 1989. Isolation and direct complete nucleotide determination of entire genes. Characterization of a gene coding for $16 \mathrm{~S}$ ribosomal RNA. Nucleic acids research 17:7843-7853. DOI: 10.1093/nar/17.19.7843.

Edwards IP., Turco RF. 2005. Inter- and intraspecific resolution of nrDNA TRFLP assessed by computer-simulated restriction analysis of a diverse collection of ectomycorrhizal fungi. Mycological Research 109:212-226. DOI: 10.1017/S0953756204002151.

van Elsas JD., Boersma FGH. 2011. A review of molecular methods to study the microbiota of soil and the mycosphere. European Journal of Soil Biology 47:77-87. DOI: 10.1016/j.ejsobi.2010.11.010.

Faust K., Lahti L., Gonze D., de Vos WM., Raes J. 2015. Metagenomics meets time series analysis: Unraveling microbial community dynamics. Current Opinion in Microbiology 25:56-66. DOI: 10.1016/j.mib.2015.04.004.

Fredriksson N., Hermansson M., Wilén B-M. 2014. Impact of T-RFLP data analysis choices on assessments of microbial community structure and dynamics. BMC bioinformatics 15:360. DOI: $10.1186 / \mathrm{s} 12859-014-0360-8$.

Frey B., Kremer J., Rüdt A., Sciacca S., Matthies D., Lüscher P. 2009. Compaction of forest 
578

579

580

581

582

583

584

585

586

587

588

589

590

591

592

593

594

595

596

597

598

599

600

601

602

603

604

605

soils with heavy logging machinery affects soil bacterial community structure. European Journal of Soil Biology 45:312-320. DOI: 10.1016/j.ejsobi.2009.05.006.

Gonzalez-Gil G., Holliger C. 2011. Dynamics of microbial community structure of and enhanced biological phosphorus removal by aerobic granules cultivated on propionate or acetate. Applied and Environmental Microbiology 77:8041-8051. DOI: 10.1128/AEM.05738-11.

Good IJ. 1953. The population frequencies of species and the estimation of population parameters. Biometrika 40:237-264.

Goropashnaya A V., Fedorov VB., Seifert B., Pamilo P. 2007. Phylogeography and population structure in the ant Formica exsecta (Hymenoptera, Formicidae ) across Eurasia as reflected by mitochondrial DNA variation and microsatellites. Annales Zoologici Fennici 2450:462474.

He H., Chen Y., Zhang Y., Wei C. 2011. Bacteria Associated with Gut Lumen of Camponotus japonicus Mayr. Environmental Entomology 40:1405-1409. DOI: 10.1603/EN11157.

Hughes WOH., Thomsen L., Eilenberg J., Boomsma JJ. 2004. Diversity of entomopathogenic fungi near leaf-cutting ant nests in a neotropical forest, with particular reference to Metarhizium anisopliae var. anisopliae. Journal of invertebrate pathology 85:46-53. DOI: 10.1016/j.jip.2003.12.005.

Ihrmark K., Bödeker ITM., Cruz-Martinez K., Friberg H., Kubartova A., Schenck J., Strid Y., Stenlid J., Brandström-Durling M., Clemmensen KE., Lindahl BD. 2012. New primers to amplify the fungal ITS2 region - evaluation by 454-sequencing of artificial and natural communities. FEMS Microbiology Ecology 82:666-677. DOI: 10.1111/j.15746941.2012.01437.x.

Jankowski K., Schindler DE., Horner-Devine MC. 2014. Resource Availability and Spatial Heterogeneity Control Bacterial Community Response to Nutrient Enrichment in Lakes. PLoS ONE 9:e86991. DOI: 10.1371/journal.pone.0086991.

Johansson H., Dhaygude K., Lindström S., Helanterä H., Sundström L., Trontti K. 2013. A metatranscriptomic approach to the identification of microbiota associated with the ant Formica exsecta. PLOS ONE 8. DOI: 10.1371/journal.pone.0079777. 
606 Jurgensen MF., Finér L., Domisch T., Kilpeläinen J., Punttila P., Ohashi M., Niemelä P.,

607

608

609

610

611

612

613

614

615

616

617

618

619

Sundström L., Neuvonen S., Risch a. C. 2008. Organic mound-building ants: Their impact on soil properties in temperate and boreal forests. Journal of Applied Entomology 132:266275. DOI: 10.1111/j.1439-0418.2008.01280.x.

Kautz S., Rubin BER., Russell J a., Moreaua CS. 2013. Surveying the microbiome of ants: Comparing 454 pyrosequencing with traditional methods to uncover bacterial diversity. Applied and Environmental Microbiology 79:525-534. DOI: 10.1128/AEM.03107-12.

Kent AD., Smith DJ., Benson BJ., Triplett W., Triplett EW. 2003. Web-Based Phylogenetic Assignment Tool for Analysis of Terminal Restriction Fragment Length Polymorphism Profiles of Microbial Communities. Applied and environmental microbiology 69:6798. DOI: 10.1128/AEM.69.11.6768.

Kilpeläinen J., Finér L., Niemelä P., Domisch T., Neuvonen S., Ohashi M., Risch a. C., Sundström L. 2007. Carbon, nitrogen and phosphorus dynamics of ant mounds (Formica rufa group) in managed boreal forests of different successional stages. Applied Soil Ecology 36:156-163. DOI: 10.1016/j.apsoil.2007.01.005.

Kõljalg U., Nilsson RH., Abarenkov K., Tedersoo L., Taylor AFS., Bahram M., Bates ST., Bruns TD., Bengtsson-Palme J., Callaghan TM., Douglas B., Drenkhan T., Eberhardt U., Dueñas M., Grebenc T., Griffith GW., Hartmann M., Kirk PM., Kohout P., Larsson E., Lindahl BD., Lücking R., Martín MP., Matheny PB., Nguyen NH., Niskanen T., Oja J., Peay KG., Peintner U., Peterson M., Põldmaa K., Saag L., Saar I., Schüßler A., Scott JA., Senés C., Smith ME., Suija A., Taylor DL., Telleria MT., Weiss M., Larsson KH. 2013. Towards a unified paradigm for sequence-based identification of fungi. Molecular Ecology 22:52715277. DOI: $10.1111 / \mathrm{mec} .12481$.

De La Fuente G., Belanche A., Girwood SE., Pinloche E., Wilkinson T., Newbold CJ. 2014. Pros and cons of ion-torrent next generation sequencing versus terminal restriction fragment length polymorphism T-RFLP for studying the rumen bacterial community. PLoS ONE 9. DOI: 10.1371/journal.pone.0101435.

Lanzén A., Epelde L., Garbisu C., Anza M., Martín-Sánchez I., Blanco F., Mijangos I. 2015. The Community Structures of Prokaryotes and Fungi in Mountain Pasture Soils are Highly 
635 Correlated and Primarily Influenced by pH. Frontiers in microbiology 6:1321. DOI:

$636 \quad 10.3389 /$ fmicb.2015.01321.

637 Larkin MA., Blackshields G., Brown NP., Chenna R., McGettigan PA., McWilliam H., Valentin 638 F., Wallace IM., Wilm A., Lopez R., Thompson JD., Gibson TJ., Higgins DG. 2007. Clustal 639 W and Clustal X version 2.0. Bioinformatics 23:2947-2948. DOI:

$640 \quad$ 10.1093/bioinformatics/btm404.

641 Lazzaro A., Hilfiker D., Zeyer J. 2015. structures of microbial communities in alpine soils:

642 Seasonal and elevational effects. Frontiers in Microbiology 6:article 1330. DOI:

$643 \quad 10.3389 /$ fmicb.2015.01330.

644 Lin Y Te., Jangid K., Whitman WB., Coleman DC., Chiu CY. 2011. Soil bacterial communities 645 in native and regenerated perhumid montane forests. Applied Soil Ecology 47:111-118. 646 DOI: 10.1016/j.apsoil.2010.11.008.

647 Lindahl B., Nilsson RH., Tedersoo L., Abarenkov K., Carlsen T., Pennanen T., Stenlid J. 2013. 648 Fungal community analysis by high-throughput sequencing of amplified markers - a user 649 s guide. New Phytologist:288-299.

650 Liu WT., Marsh TL., Cheng H., Forney LJ. 1997. Characterization of microbial diversity by 651 determining terminal restriction fragment length polymorphisms of genes encoding $16 \mathrm{~S}$ 652 rRNA. Applied and Environmental Microbiology 63:4516-4522.

653 Martin KJ., Rygiewicz PT. 2005. Fungal-specific PCR primers developed for analysis of the ITS 654 region of environmental DNA extracts. BMC microbiology 5:28. DOI: 10.1186/1471-2180$655 \quad 5-28$.

656 Marzorati M., Wittebolle L., Boon N., Daffonchio D., Verstraete W. 2008. How to get more out 657 of molecular fingerprints: Practical tools for microbial ecology. Environmental 658 Microbiology 10:1571-1581. DOI: 10.1111/j.1462-2920.2008.01572.x.

659 Vander Meer R. 2012. Ant Interactions with Soil Organisms and Associated Semiochemicals. 660 Journal of Chemical Ecology 38:728-745. DOI: 10.1007/s10886-012-0140-8.

661 Meiser A., Bálint M., Schmitt I. 2014. Meta-analysis of deep-sequenced fungal communities 662 indicates limited taxon sharing between studies and the presence of biogeographic patterns. 
664 Mertens B., Boon N., Verstraete W. 2005. Stereospecific effect of hexachlorocyclohexane on 665 activity and structure of soil methanotrophic communities. Environmental Microbiology 666 7:660-669. DOI: 10.1111/j.1462-2920.2004.00735.x.

667

Morton JT., Toran L., Edlund A., Metcalf JL., Lauber C., Knight R. 2017. Uncovering the 668 Horseshoe Effect in Microbial Analyses. mSystems 2:e00166-16. DOI:

Muehling M., Poehlein A., Stuhr A., Voitel M., Daniel R., Schl??mann M. 2016. Reconstruction of the metabolic potential of acidophilic sideroxydans strains from the metagenome of an microaerophilic enrichment culture of acidophilic iron-oxidizing bacteria from a pilot plant for the treatment of acid mine drainage reveals metabolic. Frontiers in Microbiology 7:116. DOI: $10.3389 /$ fmicb.2016.02082.

Nilsson RH., Ryberg M., Abarenkov K., Sjökvist E., Kristiansson E. 2009. The ITS region as a target for characterization of fungal communities using emerging sequencing technologies. FEMS Microbiology Letters 296:97-101. DOI: 10.1111/j.1574-6968.2009.01618.x.

680

Nocker A., Burr M., Camper AK. 2007. Microbial Ecology Genotypic Microbial Community

681

682

683

684

685

686

687

688

689

690 Profiling: A Critical Technical Review. Microbial ecology 54:276-289. DOI: 10.1007/s00248-006-9199-5.

Oksanen J., Blanchet F., Kindt R., Legendre P., Minchin P., Al. E. 2011. Vegan: Community Ecology Package. R package version 2.0-1.

Pilloni G., Granitsiotis MS., Engel M., Lueders T. 2012. Testing the limits of 454 pyrotag sequencing: Reproducibility, quantitative assessment and comparison to T-RFLP fingerprinting of aquifer microbes. PLoS ONE 7:e40467. DOI:

10.1371/journal.pone.0040467.

Prakash O., Pandey PK., Kulkarni GJ., Mahale KN., Shouche YS. 2014. Technicalities and Glitches of Terminal Restriction Fragment Length Polymorphism (T-RFLP). Indian Journal of Microbiology 54:255-261. DOI: 10.1007/s12088-014-0461-0.

Quast C., Pruesse E., Yilmaz P., Gerken J., Schweer T., Yarza P., Peplies J., Glöckner FO. 2013. 
691

692

693

694

695

696

697

698

699

700

701

702

703

704

705

706

707

708

709

710

711

712

713

714

715

716

717

718

The SILVA ribosomal RNA gene database project: improved data processing and webbased tools. Nucleic acids research 41:590-6. DOI: 10.1093/nar/gks1219.

Ramette A. 2009. Quantitative community fingerprinting methods for estimating the abundance of operational taxonomic units in natural microbial communities. Applied and environmental microbiology 75:2495-505. DOI: 10.1128/AEM.02409-08.

Robinson CH., Szaro TM., Izzo AD., Anderson IC., Parkin PI., Bruns TD. 2009. Spatial distribution of fungal communities in a coastal grassland soil. Soil Biology and Biochemistry 41:414-416. DOI: 10.1016/j.soilbio.2008.10.021.

Russell JA., Moreau CS., Goldman-Huertas B., Fujiwara M., Lohman DJ., Pierce NE. 2009. Bacterial gut symbionts are tightly linked with the evolution of herbivory in ants. PNAS $106: 21236-21241$.

Schütte UME., Abdo Z., Bent SJ., Shyu C., Williams CJ., Pierson JD., Forney LJ. 2008. Advances in the use of terminal restriction fragment length polymorphism (T-RFLP) analysis of $16 \mathrm{~S}$ rRNA genes to characterize microbial communities. Applied Microbiology and Biotechnology 80:365-380. DOI: 10.1007/s00253-008-1565-4.

Schwarzenbach K., Enkerli J., Widmer F. 2007. Objective criteria to assess representativity of soil fungal community profiles. Journal of Microbiological Methods 68:358-366. DOI: 10.1016/j.mimet.2006.09.015.

Sundstrom L., Chapuisat M., Keller L. 1996. Conditional Manipulation of Sex Ratios by Ant Workers: A Test of Kin Selection Theory. Science 274:993-995. DOI: 10.1126/science.274.5289.993.

Sundström L., Keller L., Chapuisat M. 2003. Inbreeding and sex-biased gene flow in the ant Formica exsecta. Evolution; international journal of organic evolution 57:1552-1561. DOI: 10.1111/j.0014-3820.2003.tb00363.x.

Supramaniam Y., Chong C-W., Silvaraj S., Tan IK-P. 2016. Effect of short term variation in temperature and water content on the bacterial community in a tropical soil. Applied Soil Ecology 107:279-289. DOI: 10.1016/j.apsoil.2016.07.003. 
719

720

721

722

723

724

725

726

727

728

729

730

731

732

733

734

735

736

737

738

739

740

741

742

743

744

745

746

Dunbar M., Panagos P., Groot G., Lemanceau P., Pante E., Schoelinck C., Puillandre N., Quince C., Lanzen A., Curtis T., Davenport R., Hall N., Head I., Whitlock M., Critescu M., Wieczorek J., Bloom D., Guralnick R., Blum S., Döring M., Robertson V., Yilmaz P., Kottmann R., Field D., Knight R., Cole J., Amaral-Zettler L., Meiser A., Balint M., Schmitt I., Kõljalg U., Nilsson R., Abarenkov K., Tedersoo L., Taylor A., Bahram M., Ratnasingham S., Hebert P., Abarenkov K., Tedersoo L., Nilsson R., Vellak K., Saar I., Veldre V. 2015. Standardizing metadata and taxonomic identification in metabarcoding studies. GigaScience 4:34. DOI: 10.1186/s13742-015-0074-5.

Teeling H., Glöckner FO. 2012. Current opportunities and challenges in microbial metagenome analysis-A bioinformatic perspective. Briefings in Bioinformatics 13:728-742. DOI: 10.1093/bib/bbs039.

Thies JE. 2007. Soil Microbial Community Analysis using Terminal Restriction Fragment Length Polymorphisms. Soil Science Society of America Journal 71:579. DOI: 10.2136/sssaj2006.0318.

Timonen S., Sinkko H., Sun H., Sietiö OM., Rinta-Kanto JM., Kiheri H., Heinonsalo J. 2017. Ericoid Roots and Mycospheres Govern Plant-Specific Bacterial Communities in Boreal Forest Humus. Microbial Ecology 73:939-953. DOI: 10.1007/s00248-016-0922-6.

Větrovský T., Baldrian P., Pijl A., Hollander M de., Kowalchuk G. 2013. The Variability of the 16S rRNA Gene in Bacterial Genomes and Its Consequences for Bacterial Community Analyses. PLoS ONE 8:e57923. DOI: 10.1371/journal.pone.0057923.

Vitikainen E., Haag-Liautard C., Sundström L. 2011. Inbreeding and reproductive investment in the ant formica exsecta. Evolution 65:2026-2037. DOI: 10.1111/j.1558-5646.2011.01273.x.

Voglmayr H., Mayer V., Maschwitz U., Moog J., Djieto-Lordon C., Blatrix R. 2011. The diversity of ant-associated black yeasts: Insights into a newly discovered world of symbiotic interactions. Fungal Biology 115:1077-1091. DOI: 10.1016/j.funbio.2010.11.006.

De Vries FT., Shade A. 2013. Controls on soil microbial community stability under climate change. Frontiers in Microbiology 4:1-16. DOI: 10.3389/fmicb.2013.00265.

Wade JR., Marchesi JR., Sato T., Weightman AJ., Martin TA., Fry JC., Hiom SJ., Dymock D., 
747

748

749

750

751

752

753

754

755

756

757

758

759

760

761

762

763

764

765

766

767

768

769

770

771

772

773

774

Wade WG. 1998. Design and evaluation of useful bacterium-specific PCR primers that amplify genes coding for bacterial 16S rRNA. Applied and environmental microbiology 64:795-799.

Wagg C., Bender SF., Widmer F., van der Heijden MGA. 2014. Soil biodiversity and soil community composition determine ecosystem multifunctionality. Proceedings of the National Academy of Sciences 111:5266-5270. DOI: 10.1073/pnas.1320054111.

Wang Q., Garrity GM., Tiedje JM., Cole JR. 2007. Naive Bayesian classifier for rapid assignment of rRNA sequences into the new bacterial taxonomy. Applied and environmental microbiology 73:5261-7. DOI: 10.1128/AEM.00062-07.

Weisburg WG., Barns SM., Pelletier DA., Lane DJ. 1991. 16S ribosomal DNA amplification for phylogenetic study. Journal of bacteriology 173:697-703. DOI: 10.1128/JB.173.2.697703.1991.

Weiss S., Van Treuren W., Lozupone C., Faust K., Friedman J., Deng Y., Xia LC., Xu ZZ., Ursell L., Alm EJ., Birmingham A., Cram JA., Fuhrman JA., Raes J., Sun F., Zhou J., Knight R. 2016. Correlation detection strategies in microbial data sets vary widely in sensitivity and precision. The ISME Journal 10:1669-1681. DOI: 10.1038/ismej.2015.235.

Weissbrodt DG., Shani N., Sinclair L., Lefebvre G., Rossi P., Maillard J., Rougemont J., Holliger C. 2012. PyroTRF-ID: a novel bioinformatics methodology for the affiliation of terminal-restriction fragments using $16 \mathrm{~S}$ rRNA gene pyrosequencing data. $B M C$ Microbiology 12:1471-2180.

White TJ., Bruns T., Lee S., Taylor J. 1990. PCR protocols: a guide to methods and application. San Dego: Academic Press.

Wittebolle L., Marzorati M., Clement L., Balloi A., Daffonchio D., De Vos P., Heylen K., Verstraete W., Boon N. 2009. Initial community evenness favours functionality under selective stress. Nature 458:623-6. DOI: 10.1038/nature07840.

Wittebolle L., Vervaeren H., Verstraete W., Boon N. 2008. Quantifying community dynamics of nitrifiers in functionally stable reactors. Applied and Environmental Microbiology 74:286293. DOI: 10.1128/AEM.01006-07. 
775 Youssef NH., Elshahed MS. 2009. Diversity rankings among bacterial lineages in soil. The ISME 776 Journal 3:305-313. DOI: 10.1038/ismej.2008.106.

777 Zhou J., Kang S., Schadt CW., Garten CT. 2008. Spatial scaling of functional gene diversity 778 across various microbial taxa. PNAS 105:7768-7773.

779 


\section{Table $\mathbf{1}$ (on next page)}

The number of T-RFs and OTUs obtained, Shannon-Wiener diversity index $\left(H^{\prime}\right)$ and Good's estimate of sampling coverage.

T-RFs $n=37$ (bacteria) and $n=36$ (fungi); OTUs $n=38$ for both bacteria and fungi. 
1

\begin{tabular}{|c|c|c|c|c|c|c|}
\hline & T-RFs & $S D$ & T-RFs HaeIII & T-RFs MspI & OTUs & $S D$ \\
\hline & \multicolumn{6}{|c|}{ Bacteria } \\
\hline No. of & 249 & & 129 & 120 & 4699 & \\
\hline Mean no. of (per sample) & 64 & 27 & & & 1743 & 599 \\
\hline $\begin{array}{l}\text { Mean value of Shannon- } \\
\text { Wiener H') }\end{array}$ & 3.35 & 0.43 & & & 5.69 & 0.67 \\
\hline \multirow[t]{2}{*}{ Good's estimate } & $98.0 \%$ & & $90.6 \%$ & $91.1 \%$ & $99.9 \%$ & \\
\hline & \multicolumn{6}{|c|}{ Fungi } \\
\hline No. of & 226 & & 102 & 124 & 2315 & \\
\hline Mean no. of (per sample) & 32 & 20 & & & 482 & 14 \\
\hline $\begin{array}{l}\text { Mean value of Shannon- } \\
\left.\text { Wiener } H^{\prime}\right)\end{array}$ & 2.71 & 0.76 & & & 3.48 & 0.78 \\
\hline Good's estimate & $95.0 \%$ & & $74 . \%$ & $93.0 \%$ & $99.4 \%$ & \\
\hline
\end{tabular}

2 
Figure 1

Species accumulation curves for bacterial T-RFs (A) and OTUs (B), and fungal T-RFs (C) and OTUs (D).

The line represents the actual sampling, the grey area depicts the standard deviation and the box plot shows the species richness based on linear intrapolation of random permutations.
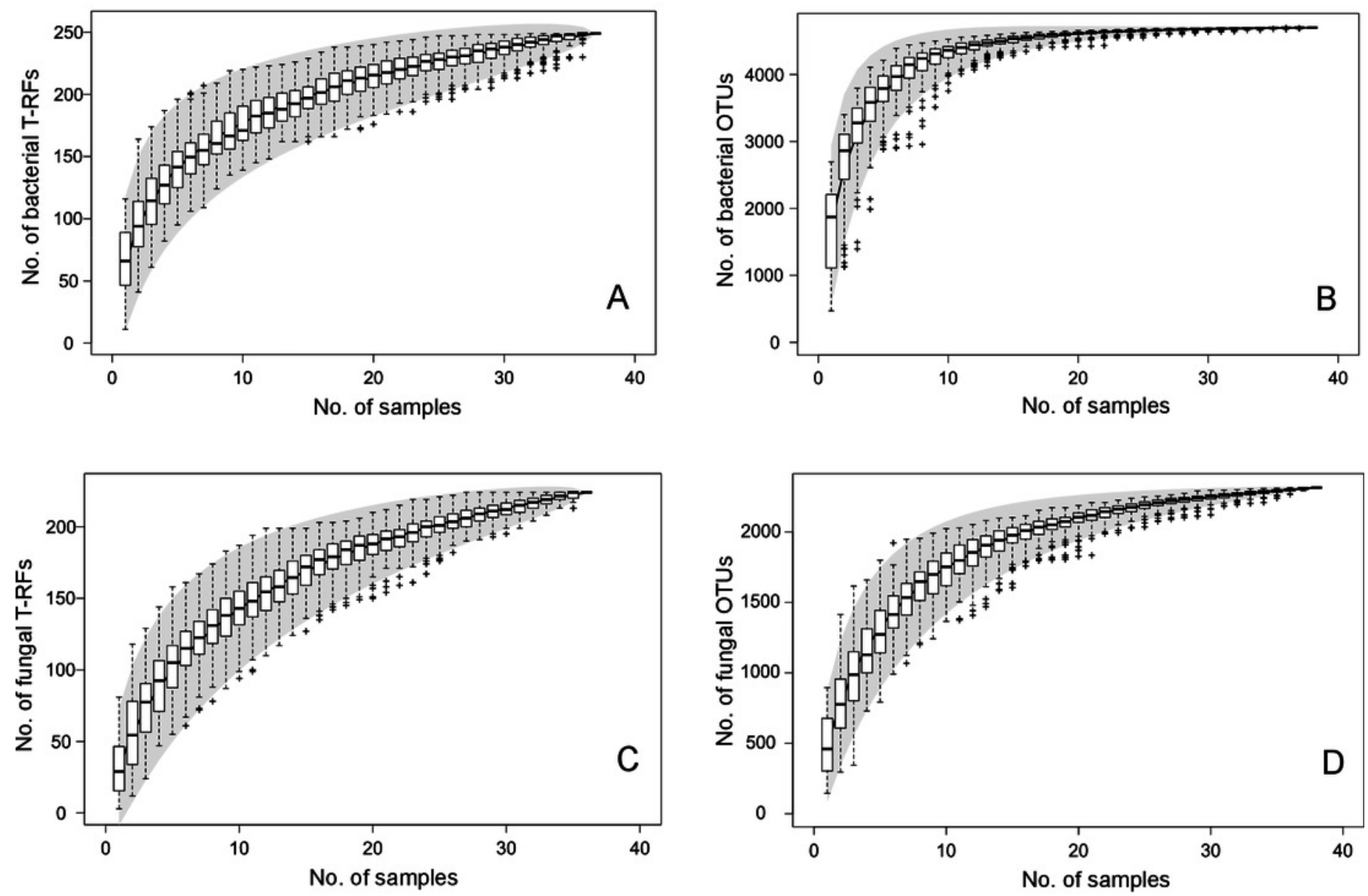


\section{Figure 2}

Functional organization (Fo) according to the Pareto-Lorenz curves of the bacterial (A) and fungal (B) T-RFs and OTUs. The continuous lines represent the T-RFs and the dashed lines the OTUs.

The value of Fo equals the value projected at the $y$-axis where the critical $20 \%$ at the $x$-axis (thin continuous line) intercepts with the Pareto-Lorenz curves. The dotted line shows the $45^{\circ}$ slope, representing perfect evenness. A Fo value of $25 \%$ represents a community of high evenness with no distinct structure in terms of species dominance. A community at the Fo value of $45 \%$ is more functionally organized due to its evenness, and a value of $80 \%$ for the Fo stands for a highly specialized community, dominated by a low number of species on which the functional stability depends.
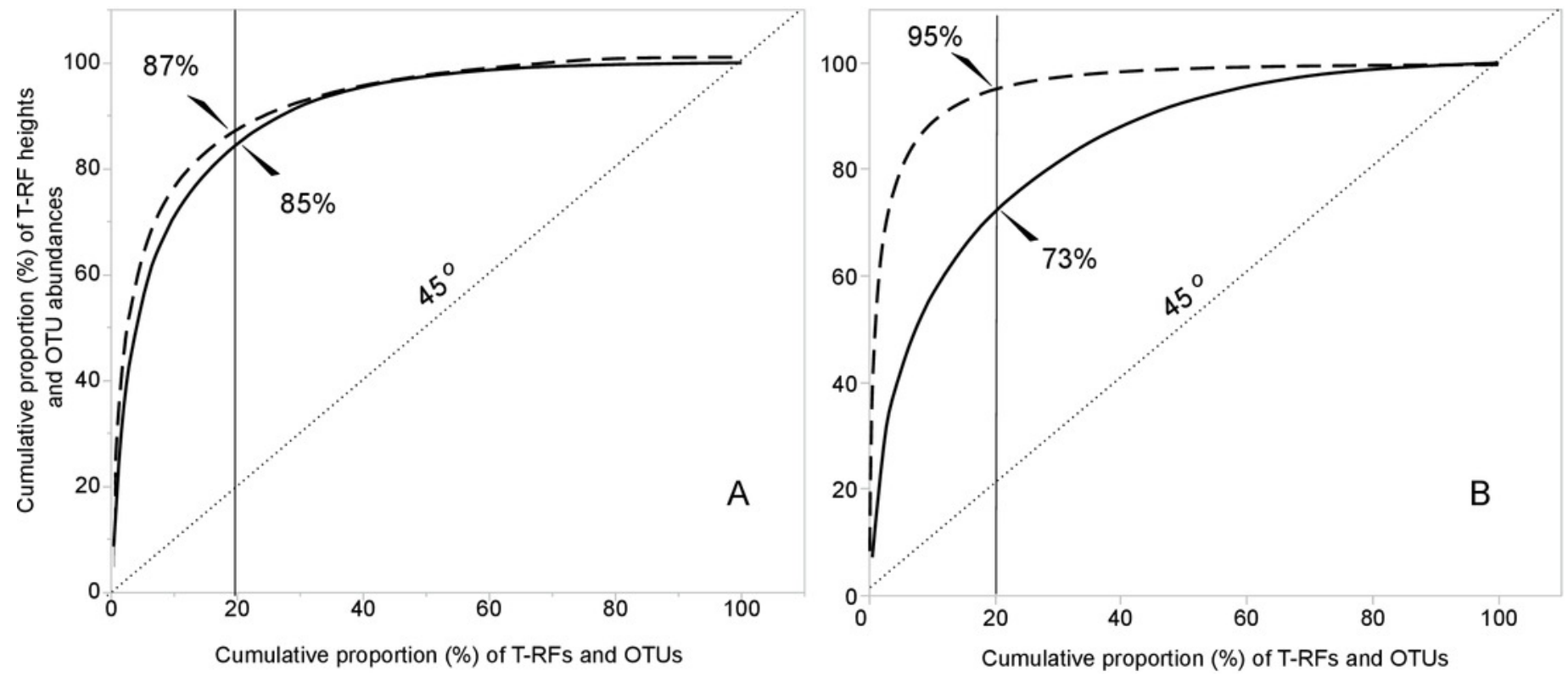
Figure 3

PCoA of bacterial T-RFs (A) and OTUs (B), and fungal T-RFs (C) and OTUs (D).

Year is indicated by colour and nest by shape of symbols as indicated in the graph.
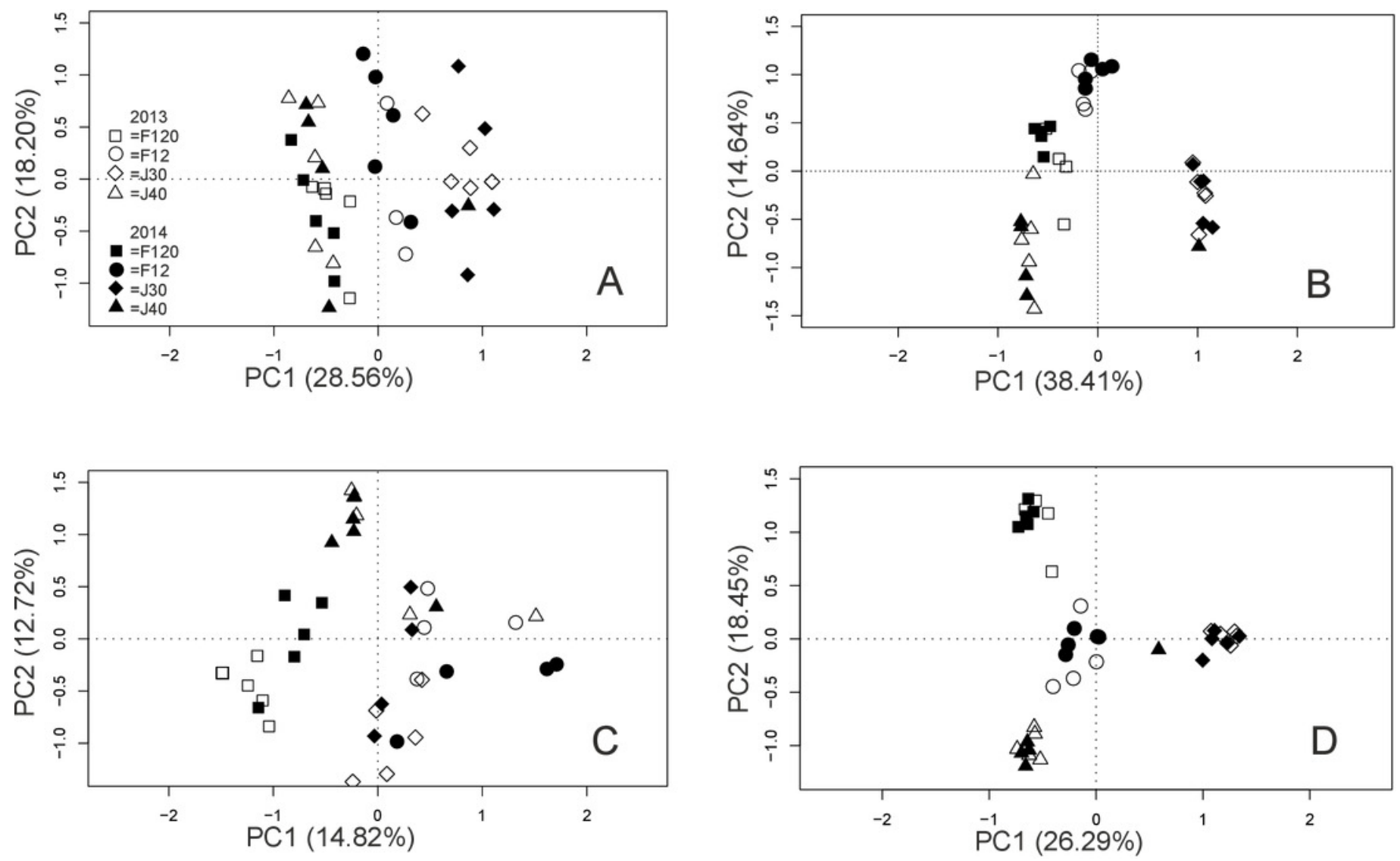


\section{Table 2 (on next page)}

PERMANOVA test of the temporal (year and month) and spatial (island and nest) effects on the Bray-Curtis distances of the bacterial and fungal T-RF and OTU data. 
1

\begin{tabular}{|c|c|c|c|c|c|c|c|c|}
\hline & \multicolumn{4}{|c|}{ T-RFs } & \multicolumn{4}{|c|}{ OTUs } \\
\hline $\begin{array}{l}\text { Test } \\
\text { effect }\end{array}$ & $F$ & $d f$ & $R^{2}$ & $p$ & $F$ & $d f$ & $R^{2}$ & $p$ \\
\hline & \multicolumn{8}{|c|}{ Bacteria } \\
\hline year & 1.08 & 36 & 0.030 & 0.336 & 0.49 & 37 & 0.014 & 0.873 \\
\hline island & 2.50 & 36 & 0.067 & 0.021 & 6.84 & 37 & 0.160 & 0.001 \\
\hline nest & 3.58 & 36 & 0.093 & 0.001 & 4.20 & 37 & 0.104 & 0.005 \\
\hline month & 2.55 & 36 & 0.068 & 0.020 & 1.32 & 37 & 0.035 & 0.210 \\
\hline & \multicolumn{8}{|c|}{ Fungi } \\
\hline year & 1.12 & 35 & 0.032 & 0.284 & 0.85 & 37 & 0.023 & 0.555 \\
\hline island & 2.99 & 35 & 0.081 & 0.001 & 7.46 & 37 & 0.172 & 0.001 \\
\hline nest & 4.65 & 35 & 0.120 & 0.001 & 7.31 & 37 & 0.169 & 0.001 \\
\hline month & 0.94 & 35 & 0.027 & 0.558 & 1.01 & 37 & 0.027 & 0.378 \\
\hline
\end{tabular}

2 
Figure 4

Correlation (Pearson rho) of T-RFs with the equivalent number of the most abundant OTUs, both ranked highest to lowest.

(A) HaellI, (B) Mspl generated bacterial T-RFs, (C) and (D) Haelll and Mspl generated fungal T-RFs respectively.

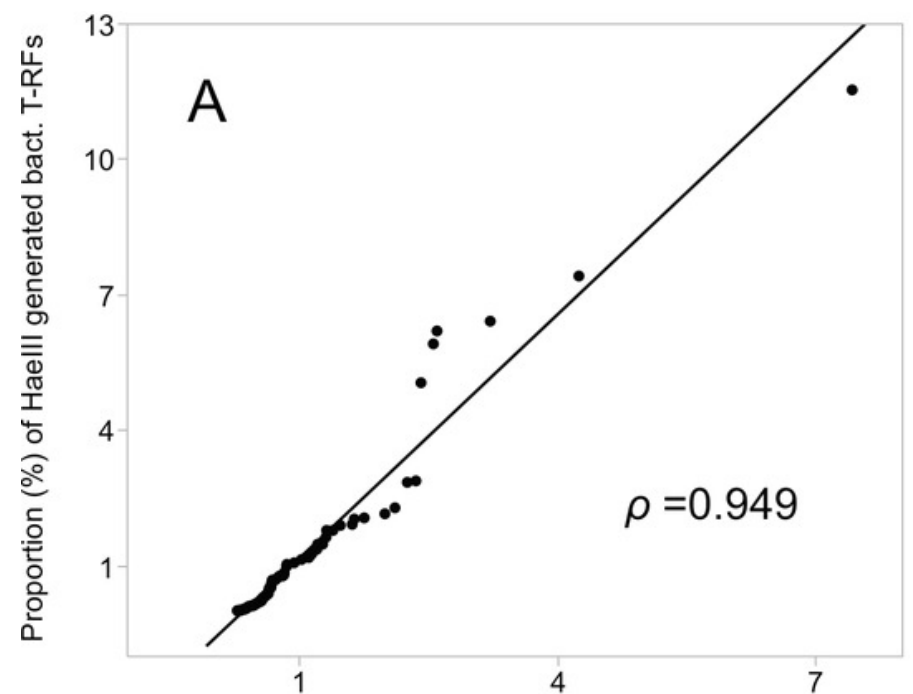

Proportion (\%) of 129 most abundant bacterial OTUs

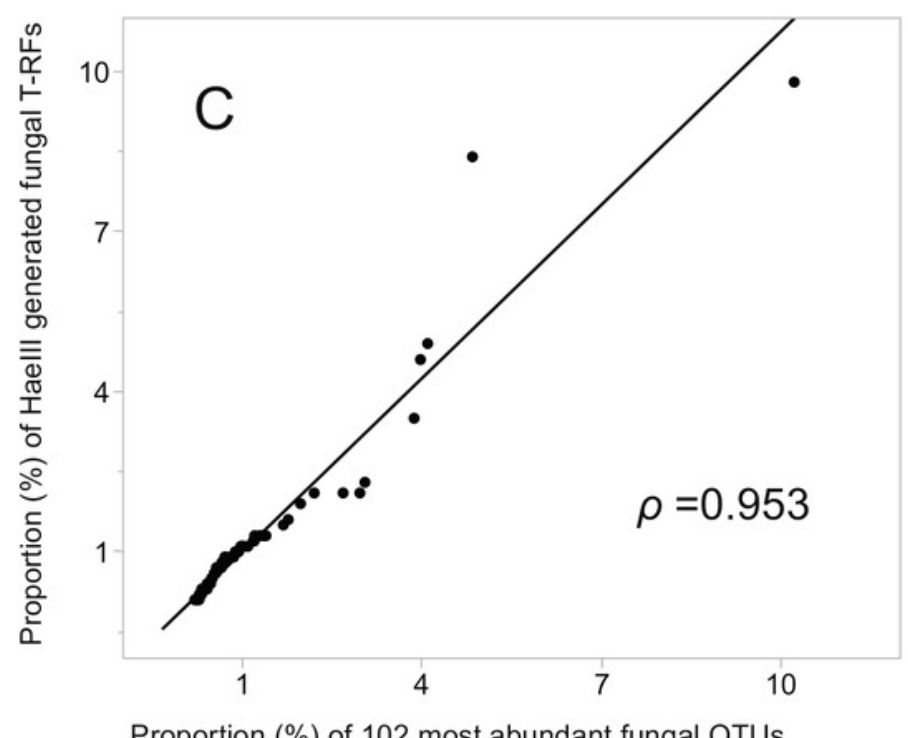

Proportion (\%) of 102 most abundant fungal OTUs

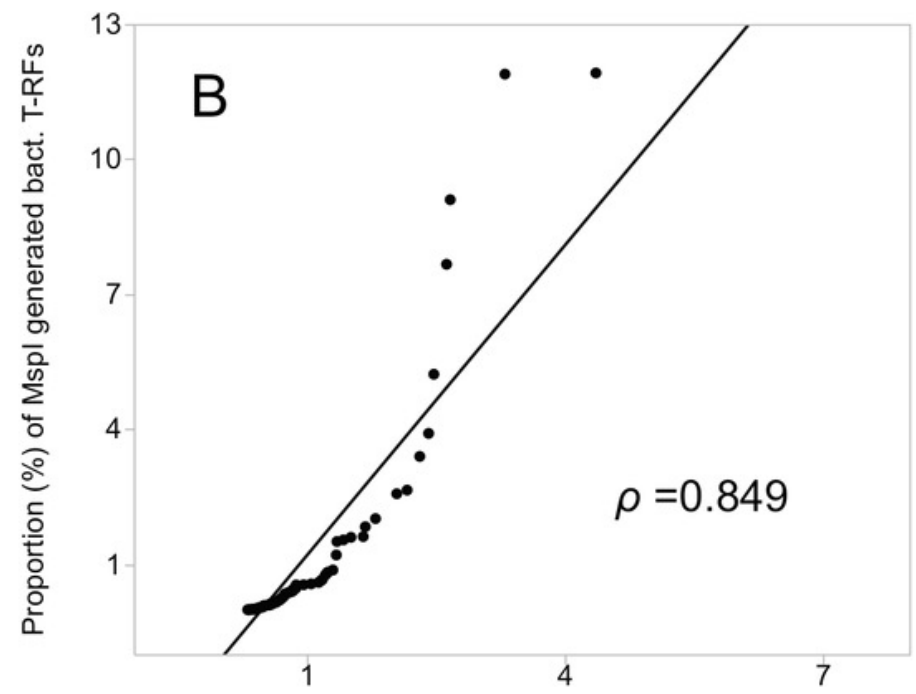

Proportion (\%) of 120 most abundant bacterial OTUs

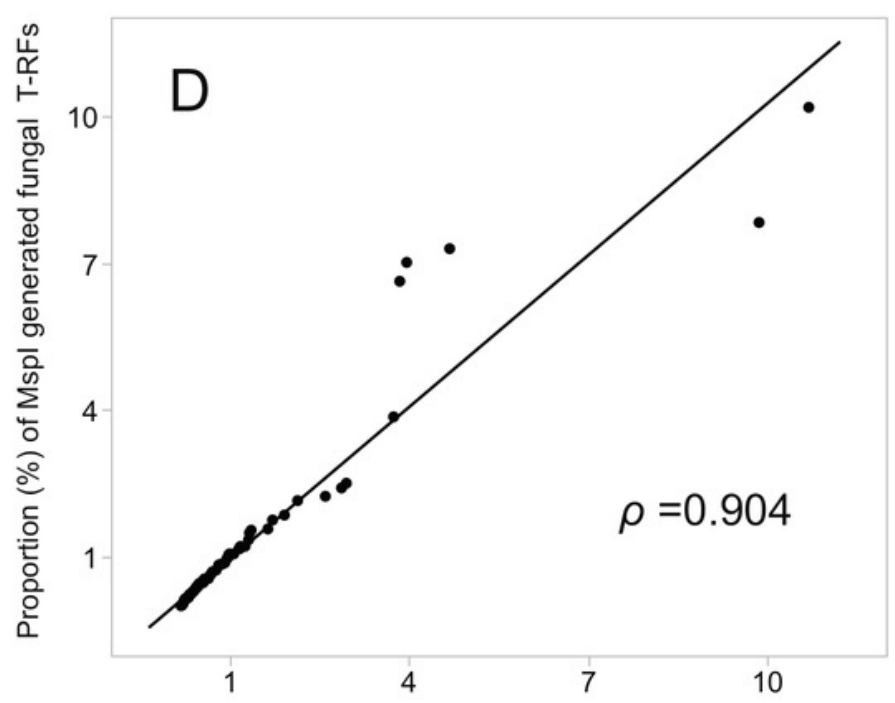

Proportion (\%) of 124 most abundant fungal OTUs 


\section{Table 3(on next page)}

The number of the Illumina MiSeq OTUs assigned to the different taxonomic levels.

The five most abundant bacterial phyla and families, together with the four fungal phyla present in the data and the five most abundant fungal families. 


\begin{tabular}{|c|c|c|}
\hline & \multicolumn{2}{|c|}{ Nbr of OTUs assigned } \\
\hline $\begin{array}{l}\text { Taxonomic } \\
\text { level: }\end{array}$ & Bacteria & Fungi \\
\hline Kingdom & 4699 & 2315 \\
\hline \multirow[t]{7}{*}{ Phylum } & 4163 & 1963 \\
\hline & $\begin{array}{l}\text { The five most abundant bacterial } \\
\text { phyla: }\end{array}$ & The four fungal phyla present in data: \\
\hline & Proteobacteria & Ascomycota \\
\hline & Actinobacteria & Basidiomycota \\
\hline & Bacteroidetes & Mucoromycota \\
\hline & Acidobacteria & Chytridiomycota \\
\hline & TM7 candidate phylum & \\
\hline Class & 3836 & 1326 \\
\hline Order & 3159 & 1105 \\
\hline \multirow[t]{7}{*}{ Family } & 2486 & 908 \\
\hline & $\begin{array}{l}\text { The five most abundant bacterial } \\
\text { families: }\end{array}$ & $\begin{array}{l}\text { The five most abundant fungal } \\
\text { families: }\end{array}$ \\
\hline & Streptomycetaceae & Herpotrichiellaceae \\
\hline & Acetobacteraceae & Sporidiobolales_Incertae_sedis \\
\hline & Nocardioidaceae & Venturiaceae \\
\hline & Caulobacteraceae & Tremellales_Incertae_sedis \\
\hline & Burkholderiaceae & Mortierellaceae \\
\hline Genus & 2031 & 725 \\
\hline
\end{tabular}

